\title{
ROLES OF DONOR/RECIPIENT BODY SURFACE AREA RATIO AND DONOR KIDNEY GLOMERULAR FILTRATION RATE IN KIDNEY SELECTION FOR LIVING TRANSPLANTATION FROM FAMILY MEMBERS
}

\author{
Youging Zheng*, Yawei Guan, Zhinul Li, Guohu Zhang and Yanje Guo, Xing Ai
}

Department of Urology, Army General Hospital of PLA, No. 5 Nanmencang, Dongsishitiao, Dongcheng District, Beijing, P. R. China

\begin{abstract}
Background: Accurate assessing donor renal function is crucial to the success of living kidney transplants. We studied the roles of donor kidney glomerular filtration rate (GFR) and donor/recipient body surface area (BSA) ratio in kidney selection for living transplantation from family members. Methods: We included 204 recipients who were subjected to living kidney transplantation from family members in our hospital from February 2011 to February 2015 and followed up for over 2 years. Recipients were divided into six groups according to donor GFR and donor/recipient BSA ratio. The effects of donor GFR or donor/recipient BSA ratio on the recovery of renal graft functions were evaluated. Results: The post-operative serum $\mathrm{creatinine}\left(\mathrm{S}_{\mathrm{Cr}}\right)$ reduction rate, steady-state $\mathrm{S}_{\mathrm{Cr}}$ level, and estimated GFR (eGFR) of the group with donor GFR $\geq 40 \mathrm{ml} / \mathrm{min}$ were slightly higher to those of the group with donor GFR $<40 \mathrm{ml} / \mathrm{min}(p>0.05)$. The renal function recovery of the group with donor/ recipient $\mathrm{BSA}$ ratio $\leq 0.8$ was significantly lower than that of the group with donor/recipient $\mathrm{BSA}$ ratio $\geq 1.2(p<0.05)$. The post-operative $\mathrm{S}_{\mathrm{Cr}}$ reduction rate, steady-state $\mathrm{S}_{\mathrm{Cr}}$ level, and eGFR of the group with $\mathrm{GFR}<40 \mathrm{ml} / \mathrm{min}$ and donor/recipient BSA ratio $\leq 0.8$ were all significantly lower than those of the other five groups $(P<0.05)$. Such values of the two groups with donor/recipient BSA ratio $>1.2$ were significantly higher than those of the other four groups $(p<0.05)$. Conclusions: The selection of donor kidneys from relatives for living kidney transplantation should also consider donor/recipient BSA ratio in addition to donor GFR. (REV INVES CLIN. 2018;70:169-76)
\end{abstract}

Key words: Glomerular filtration rate. Body surface area. Renal transplantation.

\section{INTRODUCTION}

Currently, kidney transplantation has become an effective therapy for end-stage renal failure, which not only prolongs the life of recipients but also improves their quality of life ${ }^{1,2}$. Accurate assessment of renal function is of great importance in the maintenance of adequate nephrons of renal recipients after kidney

\author{
Corresponding author: \\ *Youqing Zheng \\ Department of Urology \\ Army General Hospital of PLA, No. 5 Nanmencang \\ Dongsishitiao, Dongcheng District \\ Beijing 100700, P. R. China \\ E-mail: zhengyqaghpla@foxmail.com
}

Received for publication: 26-02-2018

Accepted for publication: 11-05-2018

doi: $10.24875 / R I C .18002518$ 
transplantation ${ }^{3}$. Glomerular filtration rate (GFR), as a sensitive marker for assessing renal function, can effectively evaluate the functions of living kidneys from family members before surgery. At present, there is still no uniform standard for donor GFR of living kidneys from family members, although in most protocols it is $\geq 40 \mathrm{ml} / \mathrm{min}$. Thereby motivated, we aimed to explore the roles of donor GFR and donor/recipient body surface area (BSA) ratio in kidney selection for living transplantation from family members.

\section{SUBJECTS AND METHODS}

\section{Baseline information}

The patients with uremia who received living kidney transplantation from family members in our hospital from February 2011 to February 2015 were selected. This study has been approved by the ethics committee of our hospital, and written consent has been obtained from all patients.

Inclusion criteria: the following criteria were included in the study: (1) recipients and their donors who underwent renal transplantation for the first time, (2) recipients and their donors who were regularly followed up in the kidney transplantation outpatient clinic of our hospital after surgery, and (3) follow-up for more than 2 years. Exclusion criteria: the following criteria were excluded from the study: (1) recipients and their donors who had received renal transplantation before and (2) recipients and their donors with perioperative vascular complications.

Finally, a total of 204 cases who required kidney transplantation due to uremia were included in this study.

\section{Pre-operative examinations}

\section{General pre-operative examinations of donors and recipients}

General pre-operative examinations included biochemical tests and imaging studies. Imaging studies included color Doppler ultrasounds for the urinary tract, digestive system, and heart.

\section{Pre-operative determination of donor GFR}

The non-radionuclide marker iohexol (Euronec 350) filtered through the glomerulus without tubular secretion was used for GFR determination. The GFR values of both of the donor's kidneys were calculated according to the clearance rate and amount of radiopharmaceutical drug ${ }^{4}$.

\section{Pre-operative determination of BSA of donors and recipients}

Mosteller method was used for the calculation of BSA: BSA $\left(\mathrm{m}^{2}\right)=($ height $\times$ weight $\left.] / 3600\right)^{1 / 2}$, height in $\mathrm{cm}$ and weight in $\mathrm{kg}^{5}$.

\section{Tissue typing}

$A B O$ blood typing, lymphotoxin test (crossmatch test), human leukocyte antigen test, and population reactive antibody test were performed ${ }^{6}$.

\section{Selection and transplantation of donor kidney}

A suitable donor and kidney were chosen according to the GFR values of both kidneys ${ }^{7}$. After a small incision was made on the waist, the left kidney was taken in 118 cases and the right kidney in 86 cases. After being excised, the donor kidney was immediately placed in and lavaged with $0^{\circ} \mathrm{C}$ hypertonic citrate adenine solution. The average time of warm ischemia during surgery was $3.21 \pm 1.54 \mathrm{~min}$ and that of cold ischemia was $28.41 \pm 14.24 \mathrm{~min}$.

\section{Surgical procedure of recipients}

After successful anesthesia, the recipient in the supine position underwent an L-shaped incision on the right lower abdomen. After internal and external iliac veins were completely free, all the bleeding points were ligated. The isolated kidney, lavaged and stored in $0^{\circ} \mathrm{C}$ hypertonic citrate adenine solution, was wrapped with ice and moved to the operating table. Then, 6-0 thread was used for the end-to-end anastomosis of renal artery and internal iliac artery. Subsequently, 5-0 thread was used for the end-to-side anastomosis of renal vein and external iliac vein ${ }^{8}$. 
Then, the surgical incision was closed outward layer by layer.

\section{Post-operative treatment of recipients}

The recipients were strictly isolated and monitored after routine renal transplantation. After surgery, particular attention was paid to their blood pressure, pulse, and central venous pressure.

\section{Immunosuppression induction regimen}

Before surgery, $80 \mathrm{mg}$ of methylprednisolone (MP) and $50 \mathrm{mg}$ of anti-thymocyte globulin (ATG) were intravenously instilled for immune induction. MP (1000 mg) was intravenously infused intraoperatively. After surgery, MP and ATG were used to prevent rejection: $500 \mathrm{mg}$ MP and $50 \mathrm{mg}$ ATG on day 1; $500 \mathrm{mg}$ $\mathrm{MP}$ and $50 \mathrm{mg}$ ATG on day 2; $375 \mathrm{mg}$ MP and $50 \mathrm{mg}$ ATG on day 3; $250 \mathrm{mg}$ MP and $50 \mathrm{mg}$ ATG on day 4; $120 \mathrm{mg}$ MP and $50 \mathrm{mg}$ ATG on day 5; and oral administration of $20 \mathrm{mg} /$ day prednisone on day 6 . The amount of post-operative oral prednisone was gradually decreased to $10 \mathrm{mg} /$ day after 3 months and to $5 \mathrm{mg} /$ day after 6 months.

\section{Immunosuppression maintenance regimen}

The recipients took oral immunosuppressive agents from the $1^{\text {st }}$ day after surgery; 174 patients took tacrolimus + mycophenolate mofetil and 30 patients received cyclosporine + mycophenolate mofetil + prednisone.

\section{Dose of tacrolimus}

CYP3A enzyme has three genotypes, i.e., $1 / * 1-$ type, ${ }^{*} 1 /{ }^{*} 3$-type, and $* 3 / * 3$-type, which evidently affect the trough value of tacrolimus dose. The initial doses for $1 /{ }^{*} 1$-type, ${ }^{*} 1 / * 3$-type, and $* 3 / * 3$-type recipients were $0.08 \mathrm{mg} / \mathrm{kg} / \mathrm{d}, 0.07 \mathrm{mg} / \mathrm{kg} / \mathrm{d}$, and $0.05 \mathrm{mg} / \mathrm{kg} / \mathrm{d}$, respectively. The renal function was monitored daily postoperatively. When the serum creatinine $\left(\mathrm{S}_{\mathrm{Cr}}\right)$ level of recipients was dropped to below $240 \mu \mathrm{mol} / \mathrm{L}$, the corresponding dose was increased: the doses of tacrolimus for $1 / * 1$-type, $* 1 / * 3$-type, and $* 3 / * 3$-type recipients were $0.15 \mathrm{mg} / \mathrm{kg} / \mathrm{d}, 0.12-0.14 \mathrm{mg} / \mathrm{kg} / \mathrm{d}$, and $0.09-0.11 \mathrm{mg} / \mathrm{kg} / \mathrm{d}$, respectively.

\section{Dose of cyclosporine}

The initial dose of cyclosporine was 6-7 mg/ $\mathrm{kg} / \mathrm{d}$. The cyclosporine concentration ( $\mathrm{C} 0$ ) was checked 3 days later. The dose of cyclosporine was adjusted according to $\mathrm{CO}$ and renal graft function. CO was usually controlled at 250-300 $\mu \mathrm{g} / \mathrm{L} 1$ week after surgery, at 200-250 $\mu \mathrm{g} / \mathrm{L} 1$ month after surgery, at 150-200 $\mu \mathrm{g} / \mathrm{L}$ 3 months after surgery, and at above $100 \mu \mathrm{g} / \mathrm{L}$ more than 6 months after surgery.

\section{Post-operative sample collection and detection}

All recipients took immunosuppressive drugs at 7:00 $\mathrm{h}$ and 19:00 h daily. Venous blood $(5 \mathrm{ml})$ was collected in the morning, half an hour $(6: 30 \mathrm{~h})$ before taking the drugs, of which $2 \mathrm{ml}$ were aliquoted in an anticoagulant tube containing ethylenediaminetetraacetic acid (EDTA) for the detection of wholeblood immunosuppressor concentration by fluorescence polarization immunoassay. Then, $1 \mathrm{ml}$ of sample in the EDTA K2 tube was used for routine blood test, and $2 \mathrm{ml}$ in the separation gel/coagulant tube was employed to detect indices such as liver and kidney functions.

\section{Detection of post-operative GFR of recipients}

Estimated GFR (eGFR) was calculated by the CKD-EPI equation: eGFR $\left(\mathrm{ml} / \mathrm{min} \cdot\left[1.73 \mathrm{~m}^{2}\right]^{-1}\right)=141 \times\left[\mathrm{S}_{\mathrm{Cr}} / \mathrm{K}\right]$ $\times$ (0.993) age $\times$ (1.018 if female). $\mathrm{S}_{\mathrm{Cr}}=$ serum creatinine. Unit for $\mathrm{S}_{\mathrm{Cr}_{\mathrm{r}}}: \mathrm{mg} / \mathrm{dL}^{9}$. $\kappa$ : Female $=0.7$, male $=0.9$. Female: $\mathrm{S}_{\mathrm{Cr}} \leq 0.7, \mathrm{a}=-0.329 ; \mathrm{S}_{\mathrm{Cr}}>0.7, \mathrm{a}=-1.209$. Male: $\mathrm{S}_{\mathrm{Cr}} \leq 0.9, \mathrm{a}=-0.411 ; \mathrm{S}_{\mathrm{Cr}}>0.9, \mathrm{a}=-1.209$.

\section{Statistical analysis}

All data were analyzed by SPSS 19.0 and expressed as mean \pm standard deviation $(x \pm s)$. The data of multiple groups with normal distribution and variance homogeneity were compared by one-way analysis of variance, and intergroup comparisons were conducted by the t-test of two independent samples. Data without normal distribution or variance homogeneity were compared by the non-parametric test. Comparisons among multiple groups were performed by the KruskalWallis $H(K)$ test, and those between two groups were carried out by the Mann-Whitney U-test. $p<0.05$ was considered to be statistically significant. 
Table 1. Baseline clinical data

\begin{tabular}{|c|c|c|c|c|c|c|c|c|c|c|c|}
\hline \multirow[t]{2}{*}{ Group } & \multirow[t]{2}{*}{$\mathrm{n}$} & \multirow[t]{2}{*}{$\begin{array}{c}\text { Age } \\
\text { (years) }\end{array}$} & \multirow{2}{*}{$\frac{\text { Gender }}{\text { (M/F) }}$} & \multicolumn{2}{|c|}{$\begin{array}{l}\text { Primary disease } \\
\text { (case) }\end{array}$} & \multirow{2}{*}{$\begin{array}{c}\begin{array}{c}\text { Pre-operative } \\
\text { serum } \\
\text { creatinine }\end{array} \\
(\mathrm{mg} / \mathrm{dL})\end{array}$} & \multirow{2}{*}{$\begin{array}{c}\text { Pre-operative } \\
\text { hemoglobin }\end{array}$} & \multirow[t]{2}{*}{$\begin{array}{c}\text { PRA } \\
\text { (positive/ } \\
\text { negative) }\end{array}$} & \multirow[t]{2}{*}{$\begin{array}{c}\text { HLA } \\
\text { (positive/ } \\
\text { negative) }\end{array}$} & \multicolumn{2}{|c|}{$\begin{array}{l}\text { MICA } \\
\text { (positive/ } \\
\text { negative) }\end{array}$} \\
\hline & & & & $\begin{array}{l}\text { Chronic } \\
\text { glomerulo- } \\
\text { nephritis }\end{array}$ & Others & & & & & 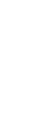 & \\
\hline A & 13 & $\begin{array}{c}28.3 \pm \\
1.4\end{array}$ & $9 / 4$ & 9 & 4 & $\begin{array}{l}9.78 \pm \\
0.25\end{array}$ & $\begin{array}{l}92.38 \pm \\
6.86\end{array}$ & $8 / 5$ & $9 / 4$ & $\frac{\dot{0}}{\frac{1}{c}}$ & $9 / 4$ \\
\hline B & 28 & $\begin{array}{c}33.5 \pm \\
1.3\end{array}$ & $23 / 5$ & 20 & 8 & $\begin{array}{l}10.19 \pm \\
0.24\end{array}$ & $\begin{array}{c}91.75 \pm \\
7.52\end{array}$ & $22 / 6$ & $23 / 5$ & & $23 / 5$ \\
\hline C & 8 & $\begin{array}{l}31.3 \pm \\
1.5\end{array}$ & $7 / 1$ & 6 & 2 & $\begin{array}{c}10.11 \pm \\
0.26\end{array}$ & $\begin{array}{l}92.51 \pm \\
7.41\end{array}$ & $6 / 2$ & $7 / 1$ & $\frac{1}{\frac{1}{+}}$ & $6 / 2$ \\
\hline D & 33 & $\begin{array}{c}29.6 \pm \\
1.1\end{array}$ & $25 / 8$ & 25 & 8 & $\begin{array}{c}10.10 \pm \\
0.28\end{array}$ & $\begin{array}{l}92.65 \pm \\
6.53\end{array}$ & $24 / 9$ & $24 / 9$ & $\frac{\circ}{\backsim}$ & $25 / 8$ \\
\hline$E$ & 98 & $\begin{array}{c}34.4 \pm \\
1.3\end{array}$ & $75 / 23$ & 68 & 30 & $\begin{array}{c}10.15 \pm \\
0.27\end{array}$ & $\begin{array}{c}91.63 \pm \\
6.84\end{array}$ & $74 / 24$ & $74 / 24$ & 7 & $75 / 23$ \\
\hline $\mathrm{F}$ & 24 & $\begin{array}{c}28.7 \pm \\
1.6\end{array}$ & $16 / 8$ & 18 & 6 & $\begin{array}{c}10.33 \pm \\
0.32\end{array}$ & $\begin{array}{c}92.51 \pm \\
7.01\end{array}$ & $16 / 8$ & $16 / 8$ & $\stackrel{c}{ \pm}$ & $16 / 8$ \\
\hline$P$ & & 0.156 & 0.875 & 0.693 & 0.431 & 0.832 & 0.791 & 0.704 & 0.903 & 3 & \\
\hline
\end{tabular}

RPA: panel reactive antibody; HAL: human leukocyte antigen; MICA: major histocompatibility complex class I-related chain A.

Table 2. Clinical data of donors

\begin{tabular}{lllllll}
\hline $\begin{array}{l}\text { Donor } \\
(\mathrm{n}=2 \text { 204) }\end{array}$ & $\begin{array}{l}\text { Age } \\
\text { (age) }\end{array}$ & $\begin{array}{l}\text { Gender } \\
\text { (male/female) }\end{array}$ & Hypertension & Diabetes & $\begin{array}{l}\text { Pre-operative } \\
\text { serum creatinine } \\
(\mathrm{mg} / \mathrm{dL})\end{array}$ & $\begin{array}{l}\text { Post-operative } \\
\text { eGFR } \\
(\mathrm{ml} / \mathrm{min})\end{array}$ \\
\hline & $45.71 \pm 9.81$ & $150 / 54$ & 0 & 0 & $0.68 \pm 0.12$ & $94.82 \pm 48.28$ \\
\hline
\end{tabular}

eGFR: estimated glomerular filtration rate.

\section{RESULTS}

\section{Baseline clinical data}

A total of 204 cases were retrospectively analyzed. There were six groups (A-F) according to the donor GFR and donor/recipient BSA ratio: GFR $<40 \mathrm{ml} / \mathrm{min}$ and donor/recipient BSA ratio $\leq 0.8$ in Group A; GFR $<40 \mathrm{ml} / \mathrm{min}$ and $0.8<$ donor/recipient BSA ratio $\leq 1.2$ in Group B; GFR < $40 \mathrm{ml} / \mathrm{min}$ and donor/recipient BSA ratio > 1.2 in Group C; GFR $\geq 40 \mathrm{ml} / \mathrm{min}$ and donor/recipient BSA ratio $\leq 0.8$ in Group D; GFR $\geq 40 \mathrm{ml} / \mathrm{min}$ and $0.8<$ donor/recipient BSA ratio $\leq$ 1.2 in Group E; and GFR $\geq 40 \mathrm{ml} / \mathrm{min}$ and donor/recipient BSA ratio > 1.2 in Group F.

The six groups had similar baseline clinical data before surgery $(p>0.05)$ (Table 1 ). During follow-up, 3 cases in Group A and 2 cases in Group B were suffered from mesangial proliferative glomerulonephritis that was confirmed by biopsy 2 months after surgery. Their creatinine levels slowly increased, and they began to receive hemodialysis again 25 months after transplantation. The other kidney functions were well maintained.

Three cases in Group E and 5 cases in Group F suffered from urine reduction, transplanted kidney swelling, and pain which were diagnosed as acute rejection response. After pulse dose therapy with MP, all the symptoms disappeared. The six groups did not present chronic rejection response during follow-up.

Clinical data of donors are listed in table 2. Donors were followed up for 2 years, without severe complications. They are all alive to this day. 
Table 3. Post-operative serum creatinine levels and eGFR values of recipients with different GFR values at different time points after surgery

\begin{tabular}{|c|c|c|c|c|c|c|c|c|}
\hline $\begin{array}{l}\text { Physical and } \\
\text { chemical indicators }\end{array}$ & Group & $\mathrm{n}$ & 1 week & 1 month & 3 months & 6 months & $\begin{array}{c}12 \\
\text { months }\end{array}$ & $\begin{array}{c}24 \\
\text { months }\end{array}$ \\
\hline \multirow{3}{*}{$\begin{array}{l}\text { Post-operative } \\
\text { serum creatinine } \\
(\mathrm{mg} / \mathrm{dl})\end{array}$} & GFR $<40$ & 50 & $\begin{array}{c}1.45 \pm \\
0.11\end{array}$ & $\begin{array}{c}1.49 \pm \\
0.09\end{array}$ & $\begin{array}{c}1.40 \pm \\
0.12\end{array}$ & $\begin{array}{c}1.30 \pm \\
0.08\end{array}$ & $\begin{array}{c}1.43 \pm \\
0.08\end{array}$ & $\begin{array}{l}1.45 \pm \\
\subset 0.09\end{array}$ \\
\hline & $\mathrm{GFR} \geq 40$ & 154 & $\begin{array}{c}1.43 \pm \\
0.10\end{array}$ & $\begin{array}{c}1.46 \pm \\
0.10\end{array}$ & $\begin{array}{c}1.39 \pm \\
0.12\end{array}$ & $\begin{array}{c}1.29 \pm \\
0.11\end{array}$ & $\begin{array}{l}1.42 \pm \\
0.08\end{array}$ & $\begin{array}{l}1.44 \pm \\
0.09\end{array}$ \\
\hline & $p$ & & 0.232 & 0.061 & 0.560 & 0.554 & 0.443 & 0.496 \\
\hline \multirow{3}{*}{$\begin{array}{l}\text { Postoperative } \\
\text { eGFR } \\
(\mathrm{ml} / \mathrm{min})\end{array}$} & GFR $<40$ & 50 & $\begin{array}{c}64.11 \pm \\
5.6\end{array}$ & $\begin{array}{c}61.15 \pm \\
4.2\end{array}$ & $\begin{array}{c}65.11 \pm \\
5.1\end{array}$ & $\begin{array}{c}69.71 \pm \\
4.8\end{array}$ & $\begin{array}{c}69.11 \pm \\
4.3\end{array}$ & $\begin{array}{l}70.31 \pm \\
4.8\end{array}$ \\
\hline & $\mathrm{GFR} \geq 40$ & 154 & $\begin{array}{c}65.17 \pm \\
4.1\end{array}$ & $\begin{array}{c}62.15 \pm \\
4.0\end{array}$ & $\begin{array}{c}65.12 \pm \\
5.3\end{array}$ & $\begin{array}{c}70.12 \pm \\
4.9\end{array}$ & $\begin{array}{c}71.14 \pm \\
4.4\end{array}$ & $\begin{array}{l}71.19 \pm \\
4.9\end{array}$ \\
\hline & $p$ & & 0.175 & 0.343 & 0.854 & 0.475 & 0.362 & 0.432 \\
\hline
\end{tabular}

eGFR: estimated glomerular filtration rate, GFR: glomerular filtration rate.

\section{Post-operative evaluation when considering GFR alone}

The post-operative $\mathrm{S}_{\mathrm{Cr}}$ reduction rate, steady-state $\mathrm{S}_{\mathrm{Cr}}$ level, and eGFR of the donor GFR $\geq 40 \mathrm{ml} / \mathrm{min}$ group were slightly higher than those of the donor GFR $<40 \mathrm{ml} / \mathrm{min}$ group $(p>0.05)$ (Table 3 ).

\section{Post-operative evaluation when considering donor/recipient BSA ratio alone}

The renal function recovery of the donor/recipient BSA ratio $\leq 0.8$ group (Group A) after surgery was significantly worse than that of the donor/recipient BSA ratio $\geq 1.2$ group (Group C) $(p<0.05)$ (Tables 4 and 5). Group B comprised recipients with $0.8<$ donor/recipient BSA ratio $<1.2$.

\section{Post-operative evaluation when simultaneously considering GFR and donor/recipient BSA ratio}

The post-operative $\mathrm{S}_{\mathrm{Cr}}$ reduction rate, steady-state $\mathrm{S}_{\mathrm{Cr}}$ level, and graft kidney eGFR of Group A were all significantly lower than those of the other five groups $(p<0.05)$. Such values of Groups C and F were significantly higher than those of the other four groups $(p<0.05)$ (Fig. 1, Tables 6 and 7).

\section{Univariate and multivariate analyses of donor GFR and donor/recipient BSA ratio}

Both univariate and multivariate analyses showed that donor GFR and donor/recipient BSA ratio were positively correlated with the post-operative kidney functions of recipients $(p<0.001$ ) (Table 8 ).

\section{DISCUSSION}

Kidney shortage is a bottleneck that has limited the development of transplantation in recent years ${ }^{10}$, which can be solved by transplanting living kidney

Figure 1. Percentage of recipients with normal serum creatinine levels 1 week after surgery

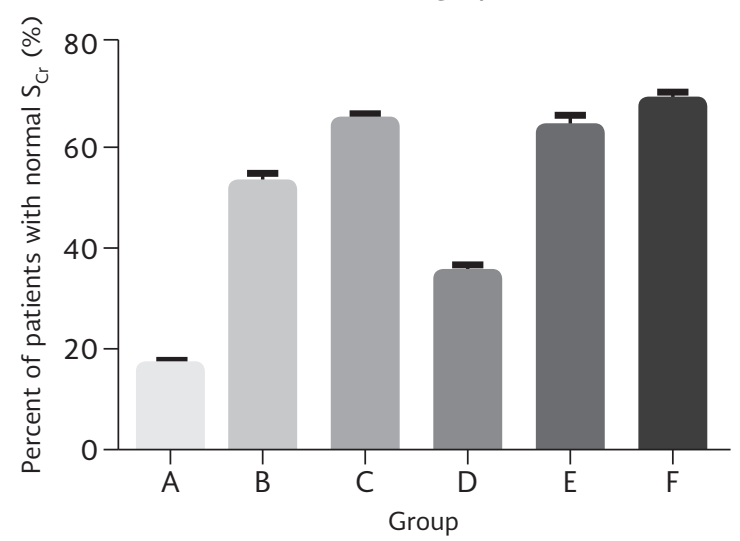


Table 4. Post-operative serum creatinine levels of recipients with different donor/recipient BSA ratios at different time points after surgery $(\mathrm{mg} / \mathrm{dL})$

\begin{tabular}{lccccccc}
\hline Groups & $\mathrm{n}$ & 1 week & 1 month & 3 months & 6 months & 12 months & 24 months \\
\hline A & 46 & $1.50 \pm 0.11$ & $1.60 \pm 0.10$ & $1.48 \pm 0.11$ & $1.45 \pm 0.08$ & $1.44 \pm 0.09$ & $1.35 \pm 0.07$ \\
B & 126 & $1.33 \pm 0.10 \mathrm{a}$ & $1.46 \pm 0.10$ & $1.41 \pm 0.10$ & $1.33 \pm 0.09$ & $1.32 \pm 0.10$ & $1.34 \pm 0.08$ \\
C & 32 & $1.20 \pm 0.12 \mathrm{a}$ & $1.20 \pm 0.10 \mathrm{a}$ & $1.15 \pm 0.11 \mathrm{a}$ & $1.03 \pm 0.08 \mathrm{a}$ & $1.01 \pm 0.10 \mathrm{ab}$ & $1.08 \pm 0.08 \mathrm{ab}$ \\
$\mathrm{p}$ & & 0.003 & 0.002 & 0.000 & 0.000 & 0.000 & 0.000 \\
\hline
\end{tabular}

${ }^{a}$ Comparison to recipients with donor/recipient BSA ratio $\leq 0.8, p<0.05$; ${ }^{b}$ Comparison to recipients with $0.8<$ donor/recipient BSA ratio $\leq 1.2, p<0.05$.

BSA: body surface area

Table 5. Post-operative eGFR values of recipients with different donor/recipient BSA ratios at different time points after surgery $(\mathrm{ml} / \mathrm{min})$

\begin{tabular}{lccccccc}
\hline Group & $\mathrm{n}$ & 1 week & 1 month & 3 months & 6 months & 12 months & 24 months \\
\hline A & 46 & $60.51 \pm 9.52$ & $56.14 \pm 8.15$ & $64.15 \pm 9.15$ & $61.51 \pm 7.15$ & $63.14 \pm 8.11$ & $65.44 \pm 6.15$ \\
B & 126 & $78.01 \pm 95.1 \mathrm{a}$ & $75.11 \pm 8.16$ & $74.16 \pm 9.11$ & $69.15 \pm 7.16$ & $69.15 \pm 8.17$ & $78.14 \pm 6.19$ \\
C & 32 & $86.18 \pm 10.13 \mathrm{a}$ & $79.91 \pm 8.19 \mathrm{a}$ & $75.15 \pm 9.14 \mathrm{a}$ & $79.93 \pm 7.13 \mathrm{a}$ & $85.27 \pm 9.11 \mathrm{ab}$ & $80.13 \pm 7.13 \mathrm{ab}$ \\
p & & 0.024 & 0.125 & 0.215 & 0.041 & 0.003 & 0.152 \\
\hline
\end{tabular}

${ }^{\mathrm{a}}$ Comparison to recipients with donor/recipient BSA ratio $\leq 0.8, \mathrm{p}<0.05 ;{ }^{\mathrm{b}}$ comparison to recipients with $0.8<$ donor/recipient $\mathrm{BSA}$ ratio $\leq 1.2$, $p<0.05$.

eGFR: estimated glomerular filtration rate, BSA: body surface area

Table 6. Serum creatinine levels at different time points after surgery $(\mathrm{mg} / \mathrm{dL})$

\begin{tabular}{lccccccc}
\hline Group & $\mathrm{n}$ & 1 week & 1 month & 3 months & 6 months & 12 months & 24 months \\
\hline A & 13 & $1.70 \pm 0.08$ & $1.82 \pm 0.09$ & $1.72 \pm 0.09$ & $1.66 \pm 0.08$ & $1.51 \pm 0.08$ & $1.61 \pm 0.07$ \\
B & 28 & $1.47 \pm 0.08$ & $1.47 \pm 0.10$ & $1.35 \pm 0.10$ & $1.28 \pm 0.08$ & $1.36 \pm 0.08$ & $1.32 \pm 0.07$ \\
C & 8 & $1.16 \pm 0.07$ & $1.12 \pm 0.07$ & $1.04 \pm 0.06$ & $1.02 \pm 0.06$ & $1.04 \pm 0.06$ & $1.03 \pm 0.05$ \\
D & 33 & $1.54 \pm 0.07$ & $1.55 \pm 0.08$ & $1.39 \pm 0.09$ & $1.39 \pm 0.09$ & $1.42 \pm 0.07$ & $1.28 \pm 0.07$ \\
E & 98 & $1.29 \pm 0.08$ & $1.45 \pm 0.09$ & $1.40 \pm 0.08$ & $1.34 \pm 0.09$ & $1.29 \pm 0.07$ & $1.35 \pm 0.07$ \\
F & 24 & $1.21 \pm 0.09$ & $1.22 \pm 0.07$ & $1.17 \pm 0.08$ & $1.02 \pm 0.10$ & $1.01 \pm 0.05$ & $1.11 \pm 0.05$ \\
P & & 0.019 & 0.092 & 0.003 & 0.019 & 0.007 & 0.215 \\
\hline
\end{tabular}

Table 7. eGFR values at different time points after surgery $(\mathrm{ml} / \mathrm{min})$

\begin{tabular}{lccccccc}
\hline Group & $\mathrm{n}$ & 1 week & 1 month & 3 months & 6 months & 12 months & 24 months \\
\hline A & 13 & $51.13 \pm 3.12$ & $48.17 \pm 2.18$ & $46.91 \pm 2.15$ & $48.15 \pm 2.17$ & $50.61 \pm 2.18$ & $50.21 \pm 2.17$ \\
B & 28 & $62.14 \pm 2.19$ & $60.15 \pm 2.51$ & $66.41 \pm 2.13$ & $67.14 \pm 2.15$ & $65.18 \pm 2.18$ & $70.15 \pm 2.16$ \\
C & 8 & $87.13 \pm 3.12$ & $82.15 \pm 2.51$ & $84.21 \pm 2.81$ & $80.14 \pm 2.17$ & $81.51 \pm 2.12$ & $83.51 \pm 2.14$ \\
D & 33 & $61.12 \pm 3.15$ & $59.16 \pm 3.41$ & $66.71 \pm 2.81$ & $63.14 \pm 2.18$ & $62.8 \pm 2.18$ & $67.51 \pm 6.11$ \\
E & 98 & $77.11 \pm 3.18$ & $67.13 \pm 2.19$ & $63.18 \pm 2.18$ & $71.15 \pm 2.17$ & $72.2 \pm 3.11$ & $70.15 \pm 2.18$ \\
F & 24 & $83.91 \pm 2.18$ & $79.12 \pm 2.19$ & $71.15 \pm 3.11$ & $82.15 \pm 2.18$ & $86.3 \pm 3.14$ & $80.15 \pm 3.14$ \\
p & & 0.023 & 0.089 & 0.002 & 0.024 & 0.006 & 0.187 \\
\hline
\end{tabular}

eGFR: estimated glomerular filtration rate 
Table 8. Univariate and multivariate analyses of donor GFR and donor/recipient BSA ratio

\begin{tabular}{|c|c|c|c|c|c|}
\hline \multirow[t]{2}{*}{ Index } & \multicolumn{3}{|c|}{ Univariate } & \multicolumn{2}{|c|}{ Multivariate } \\
\hline & $\begin{array}{l}\text { Correlation } \\
\text { coefficient }\end{array}$ & $95 \% \mathrm{Cl}$ & $p$ & $\begin{array}{l}\text { Correlation } \\
\text { coefficient }\end{array}$ & p \\
\hline Donor GFR & 0.27 & $0.17-0.37$ & $<0.001$ & 0.26 & $<0.00$ \\
\hline $\begin{array}{l}\text { Donor/recipient } \\
\text { BSA ratio }\end{array}$ & 35.74 & $20.75-50.72$ & $<0.001$ & 41.17 & $<0.00$ \\
\hline
\end{tabular}

GFR: glomerular filtration rate, BSA: body surface area, $\mathrm{Cl}$ : confidence interval.

from family members ${ }^{11}$. The prognosis is related to the quality of life of both recipient and donor. Therefore, donors should be subjected to complete, detailed, and strict general physical examinations before kidney transplantation to select the best family member $^{12,13}$.

GFR is currently a sensitive biochemical index for kidney function, but there is no uniform standard for the choice of living kidney transplantation from family members. Most transplant centers require GFR of both of the donor's kidneys to exceed $40 \mathrm{ml} / \mathrm{min}$. Thus, there is still a controversy over the selection of donor kidneys with GFR lower than $40 \mathrm{ml} / \mathrm{min}$.

BSA influences the incidence of delayed graft function and acute rejection and the recovery of renal graft function after transplantation ${ }^{14-16}$. Therefore, we should also consider the ratio of donor/recipient BSA in the living renal transplantation from family members. In our hospital, the recovery of recipient renal graft function with the donor GFR $<40 \mathrm{ml} / \mathrm{min}$ after living renal transplantation from family members was slightly worse than that of recipients with donor GFR $\geq 40 \mathrm{ml} / \mathrm{min}$. Hence, we strictly controlled the inclusion criteria of donors with GFR $<40 \mathrm{ml} / \mathrm{min}$ before surgery and took into account the donor/recipient BSA ratio, so the living donor kidney transplantations with GFR $<40 \mathrm{ml} / \mathrm{min}$ and GFR $40 \mathrm{ml} / \mathrm{min}$ had similar effects. After surgery, the $S_{C r}$ level of the group with donor GFR $<40 \mathrm{ml} / \mathrm{min}$ was slightly higher than that of the group with donor GFR $\geq 40 \mathrm{ml} / \mathrm{min}$ at each time point. Meanwhile, eGFR of the group with donor GFR $<40 \mathrm{ml} / \mathrm{min}$ was slightly lower than that of the group with donor GFR $\geq 40 \mathrm{ml} / \mathrm{min}$ at each time point. Therefore, although GFR of donor may affect the post-operative renal function of recipients, the effect may be minimized by controlling surgical indications and reasonably selecting GFR $<40 \mathrm{ml} / \mathrm{min}$ recipients.
After surgery, the group with donor/recipient BSA ratio $\leq 0.8$, the group with donor/recipient $\mathrm{BSA}$ ratio $>0.8$ to $\leq 1.2$, and the group with donor/recipient BSA ratio $>1.2$ had similar incidence rates of delayed graft function and acute rejection.

The $\mathrm{S}_{\mathrm{Cr}}$ level of the group with donor/recipient BSA ratio $\leq 0.8$ at each time point was slightly higher than those of the group with donor/recipient BSA ratio $>0.8$ to $\leq 1.2$ and the group with donor/recipient BSA ratio $>1.2$. Meanwhile, the group with donor/recipient BSA ratio $\leq 0.8$ had a slightly lower eGFR at each time point than those of the group with donor/recipient BSA ratio $>0.8$ to $\leq 1.2$ and the group with donor/recipient BSA ratio $>1.2$. Thus, the ratio of donor/recipient BSA may affect recipient renal function after transplantation to a certain extent. The $\mathrm{S}_{\mathrm{Cr}}$ levels of the six groups of recipients decreased rapidly in the $1^{\text {st }}$ week after kidney transplantation. The ratio of the recipients' group with donor GFR $<40 \mathrm{ml} /$ $\mathrm{min}$ and donor/recipient BSA $\leq 0.8$ to normal ratio was significantly lower than those of the other five groups, suggesting that the two indices significantly affected the recovery of transplanted kidney in recipients at the early stage and the early compensatory capacity of recipients was also low. The $\mathrm{S}_{\mathrm{Cr}}$ levels of the six groups of recipients decreased slowly and gradually stabilized 1 week after renal transplantation, with significant differences in the stable period. The $\mathrm{S}_{\mathrm{Cr}}$ level of the group with donor GFR $<40 \mathrm{ml} /$ min and donor/recipient BSA $\leq 0.8$ at each time point was significantly higher than those of the other five groups. The $\mathrm{S}_{\mathrm{Cr}}$ levels of the group with donor GFR $<40 \mathrm{ml} / \mathrm{min}$ and donor/recipient BSA ratio $>1.2$ and the group with donor GFR $\geq 40 \mathrm{ml} / \mathrm{min}$ and donor/ recipient BSA ratio > 1.2 were all significantly lower than those of the other four groups. The group with donor GFR $<40 \mathrm{ml} / \mathrm{min}$ and donor/recipient BSA ratio $\leq 0.8$ had a significantly lower eGFR than those of the 
other five groups at each time point. Besides, the eGFR values of the group with donor GFR $<40 \mathrm{ml} /$ min and donor/recipients BSA ratio $>1.2$ and the group with donor GFR $\geq 40 \mathrm{ml} / \mathrm{min}$ and donor/recipient $\mathrm{BSA}$ ratio $>1.2$ at each time point were significantly higher than those of the other four groups. Accordingly, donor GFR $<40 \mathrm{ml} / \mathrm{min}$ and donor/recipient BSA ratio $\leq 0.8$ obviously affected the midand long-term renal function recoveries of recipients, with unsatisfactory outcomes. The recipients with donor/recipient BSA ratio $>1.2$ recovered more rapidly, and the $S_{C r}$ level also decreased quickly to normal. In particular, the effects of donor GFR $\geq 40 \mathrm{ml} / \mathrm{min}$ and donor/recipient BSA ratio $>1.2$ were significantly different. The donors were followed up for 2 years, without severe complications. They are all alive up to this day.

In conclusion, the postoperative renal graft recovery was affected by both donor GFR and BSA of recipients. Especially, when the donor/recipient BSA ratio was $\leq 0.8$, the renal graft function of recipients with donor GFR $<40 \mathrm{ml} / \mathrm{min}$ hardly recovered to normal. Therefore, the donor kidneys with donor/recipient BSA ratio $<0.8$ and GFR $<40 \mathrm{ml} / \mathrm{min}$ should be avoided. When donor/recipient BSA ratio was $>0.8$ or $\leq 1.2$, there was no significant difference in $\mathrm{S}_{\mathrm{Cr}}$ level or eGFR at each time point after surgery between the group with donor GFR $<40 \mathrm{ml} / \mathrm{min}$ and the group with donor GFR $\geq 40 \mathrm{ml} / \mathrm{min}$. When donor/ recipient BSA ratio was $>1.2$, these two groups had similar $\mathrm{S}_{\mathrm{Cr}}$ levels and eGFR values at each time point after surgery, and the group with donor GFR $<40 \mathrm{ml} /$ min had better renal graft function at each time point than those of the group with donor/recipient BSA ratio $\leq 1.2$ and donor GFR $\geq 40 \mathrm{ml} / \mathrm{min}$. When donor/ recipient BSA ratio was $>0.8$, the effect of donor GFR on the recovery of renal graft function after surgery was attenuated, and there was no significant difference in the recovery of renal graft function between the recipients with donor GFR $<40 \mathrm{ml} / \mathrm{min}$ and GFR $\geq 40 \mathrm{ml} / \mathrm{min}$.

Thus, the ratio of donor/recipient BSA should be considered besides donor GFR in the selection of living renal transplantation from family members. For donors with donor/recipient BSA ratio $\geq 0.8$, especially those with the ratio $\geq 1.2$, GFR below $40 \mathrm{ml} / \mathrm{min}$ may also be applicable. Nevertheless, this study did not have data of time-zero biopsies in grafts of living donors. Further, in-depth studies are ongoing in our group.

\section{REFERENCES}

1. Haynes R, Harden P, Judge P, et al. Alemtuzumab-based induction treatment versus basiliximab-based induction treatment in kidney transplantation (the 3C Study): a randomised trial. Lancet. 2014:384:1684-90.

2. Stegall MD, Gaston RS, Cosio FG, Matas A. Through a glass darkly: seeking clarity in preventing late kidney transplant failure. J Am Soc Nephrol. 2015;26:20-9.

3. Levine DJ, Glanville AR, Aboyoun C, et al. Antibody-mediated rejection of the lung: a consensus report of the international society for heart and lung transplantation. J Heart Lung. 2016:35:397-406.

4. Venner JM, Hidalgo LG, Famulski KS, Chang J, Halloran PF. The molecular landscape of antibody-mediated kidney transplant rejection: evidence for NK involvement through CD16a Fc receptors. Am J Transplant. 2015;15:1336-48.

5. Hutchinson JA, Geissler EK. Now or never? The case for cellbased immunosuppression in kidney transplantation. Kidney Int. 2015;87:1116-24.

6. Haarberg KM, Tambur AR. Detection of donor-specific antibodies in kidney transplantation. Br Med Bull. 2014;110:23-34.

7. Loupy A, Haas M, Solez K, et al. The banff 2015 kidney meeting report: current challenges in rejection classification and prospects for adopting molecular pathology. Am J Transplant. 2017; 17:28-41.

8. Halloran PF, Famulski K, Reeve J. The molecular phenotypes of rejection in kidney transplant biopsies. Curr Opin Organ Transplant. 2015;20:359-67.

9. Shojaei H, Hashemi A, Heidarieh P, Hosseini N, Daei Naser A Chronic pulmonary disease due to Mycobacteriummonacense infection: the first case from Iran. Ann Lab Med. 2012;32:87-90.

10. Kulkarni S, Kirkiles-Smith NC, Deng YH, et al. Eculizumab therapy for chronic antibody-mediated injury in kidney transplant recipients: a pilot randomized controlled trial. Am j Transplant. 2017; 17:682-91

11. Anglicheau D, Naesens M, Essig M, Gwinner W, Marquet P. Establishing biomarkers in transplant medicine: a critical review of current approaches. Transplantation. 2016;100:2024-38.

12. Higgins RM, Daga S, Mitchell DA. Antibody-incompatible kidney transplantation in 2015 and beyond. Nephrol Dial Transplant. 2014;30:1972-8

13. Legris T, Picard C, Todorova D, et al. Antibody-dependent NK cell activation is associated with late kidney allograft dysfunction and the complement-independent alloreactive potential of donor-specific antibodies. Front Immunol. 2016;7:288.

14. O'Connor EM, Koufaki P, Mercer TH, et al. Long-term pulse wave velocity outcomes with aerobic and resistance training in kidney transplant recipients-A pilot randomised controlled trial. PLoS One. 2017;12:e0171063.

15. Baron PW, Infante S, Peters R, et al. Post-transplant diabetes mellitus after kidney transplant in Hispanics and caucasians treated with tacrolimus-based immunosuppression. Ann Transplant. 2017;22:309-14.

16. Wainright JL, Klassen DK, Kucheryavaya AY, Stewart DE. Delays in prior living kidney donors receiving priority on the transplant waiting list. Clin J Am Soc Nephrol. 2016;11:2047-52. 